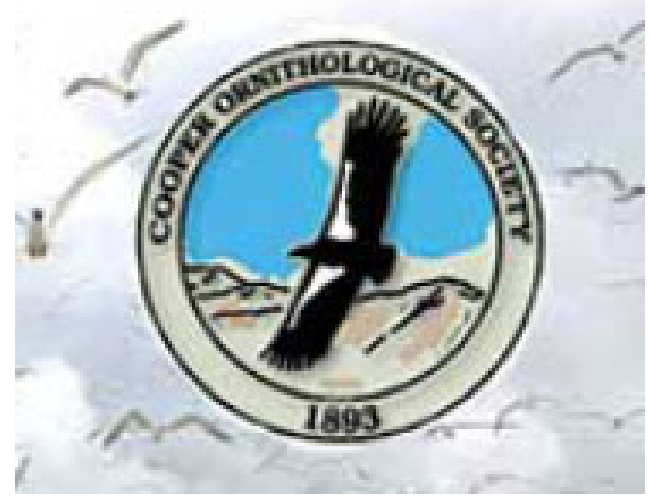

Territoriality and Mating Behavior of the Male Brown-Headed Cowbird Author(s): J. A. Darley

Source: The Condor, Vol. 84, No. 1 (Feb., 1982), pp. 15-21

Published by: University of California Press on behalf of the Cooper Ornithological Society Stable URL: http://www.jstor.org/stable/1367814

Accessed: $26 / 08 / 2013$ 14:39

Your use of the JSTOR archive indicates your acceptance of the Terms \& Conditions of Use, available at http://www.jstor.org/page/info/about/policies/terms.jsp

JSTOR is a not-for-profit service that helps scholars, researchers, and students discover, use, and build upon a wide range of content in a trusted digital archive. We use information technology and tools to increase productivity and facilitate new forms of scholarship. For more information about JSTOR, please contact support@jstor.org.

University of California Press and Cooper Ornithological Society are collaborating with JSTOR to digitize, preserve and extend access to The Condor. 


\title{
TERRITORIALITY AND MATING BEHAVIOR OF THE MALE BROWN-HEADED COWBIRD
}

\section{J. A. DARLEY}

\begin{abstract}
The social behavior of 154 banded male Brown-headed Cowbirds (Molothrus ater) was studied at London, Ontario in 1966 and 1967. Aggressive encounters between them appeared to involve either the establishment and maintenance of a dominance hierarchy or the guarding of resident females. Dominant males mated with resident females in mostly monogamous relationships. Males occupied specific ranges but did not defend them. Dominant males, however, defended their mates, and females sometimes defended their males from other females. Excess males were present and in breeding condition. They attended any female during her mate's absence, courting and guarding her from advances by other males and occasionally copulating with her.
\end{abstract}

The reproductive behavior of male Brownheaded Cowbirds (Molothrus ater) presents several interesting problems. Reports on territorial behavior are contradictory. Friedmann (1929) reported that cowbirds were territorial whereas Nice (1937) and Laskey (1950) reported that cowbirds did not defend territories. Rothstein (1972) believed male cowbirds to be territorial only at certain times of day. If territorialism exists in cowbirds, its origin differs from that in other birds because defense of a single nest site, nestlings and nestling food supply are not needed in a parasitic species. If the male is territorial, what is he defending?

Male cowbirds outnumber females by 1.5:1 (Friedmann 1929, McIlhenny 1940, Darley 1971). Scott and Middleton (1968) reported that all the males they examined were in breeding condition, based on examination of testes. If this is the case, do all males breed or are some just potential breeders restricted by the number of females? If bonds exist between males and females, how are they maintained in the presence of so many other birds?

This paper considers some observations on the defensive behavior and social relationships of male cowbirds.

\section{METHODS}

I conducted this study in 1966 and 1967 on the campus of the University of Western Ontario, London, Ontario, Canada, following individually color-banded birds throughout the breeding season from the end of March until mid-July. I presented details of banding, colormarking, and recording of behavior patterns in Darley (1971). The areas of the ranges of males were determined by plotting the outermost points of observed locations of individual birds on an aerial photograph of the study area. For this purpose, I included all activities except feeding. Feeding birds were excluded because they traveled widely and typically fed in mixed groups at areas that I had baited. After connecting the outermost points to form the range boundary, I measured the area with a planimeter. The functions of behavior patterns were described and discussed in Darley (1968). Yearlings were distinguished from adults by the presence of some juvenile feathers in an apparent adult plumage (Darley 1971). I examined the testes of some males to determine their reproductive condition. Testes were removed within $10 \mathrm{~min}$ of death, fixed for $24 \mathrm{~h}$ in Bouin's solution, and then embedded in paraffin. I cut representative 10-micron sections and stained them with Ehrlich's haematoxylin and eosin. The stained sections were examined and classified according to stages described in Scott and Middleton (1968). The statistical tests used were found in Snedecor (1956) and Steel and Torrie (1960).

\section{RESULTS}

The cowbirds returned to the campus at the end of March or îrst week in April. Adult males and females appeared first, followed two weeks later by yearling males, who were followed about a week later by yearling females. About $60 \%$ of the adults were present when the first yearlings arrived.

Male cowbirds occupied specific areas but did not defend them. Aggressive encounters of mated males (Table 1), unlike those of females (Darley 1968), were not concentrated along the boundaries of these ranges; most were seen within the boundaries.

Forty-one males were mates of breeding resident females. The range of each of these males usually overlapped most or all of his mate's territory and was normally larger. These ranges varied from 0.4 to 25.0 ha (mean $7.9 \pm 1.0$ ha; Fig. 1). When alone within his range the 


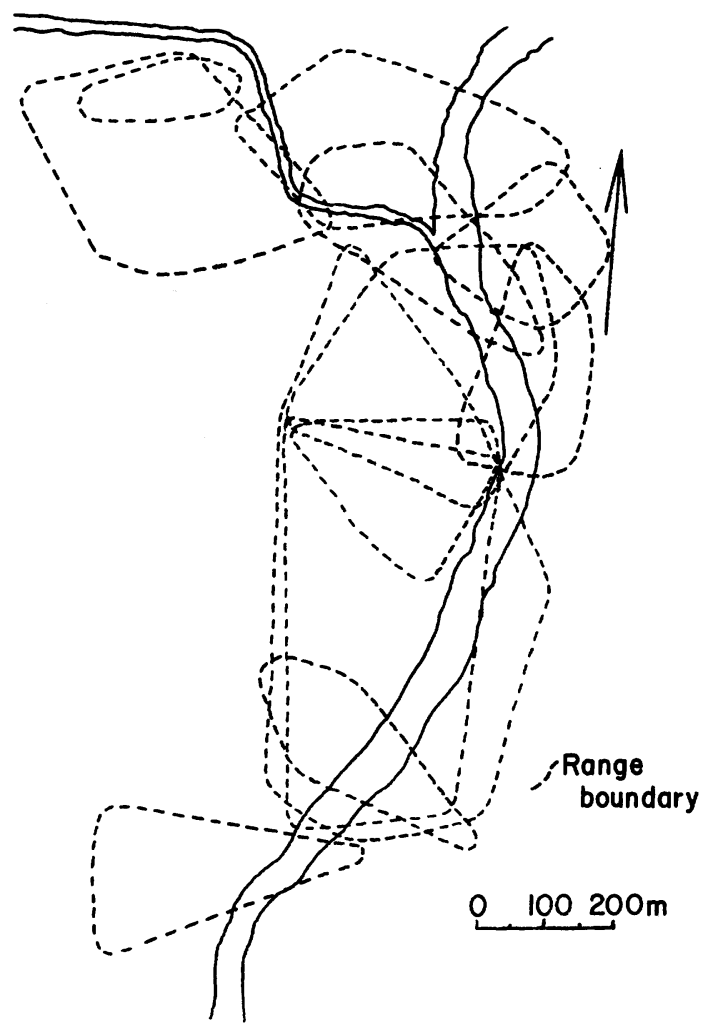

FIGURE 1. The non-feeding ranges (--) of mated resident male cowbirds at London, Ontario in 1966.

male often gave low intensity "song spread" with the accompanying "accent song" from a high perch or "singing tree" (Friedmann 1929). These displays were similar to those described by Orians and Christman (1968) for Red-winged (Agelaius phoeniceus), Tricolored (A. tricolor) and Yellow-headed blackbirds (Xanthocephalus xanthocephalus). The song was repeated from this conspicuous position and seemed to advertise the bird's presence. I noted this behavior from the time of arrival in the area until the end of the breeding season which, based on egg laying, extended from the first of May to mid-July (Scott and Ankney 1980). A male was considered mated if he was frequently observed with the female and, if other males were present, he guarded her by placing himself between the female and an approaching male and directing song spreads at the interloper. Guarding was first observed about two weeks after the birds' arrival and continued throughout the season. This behavior was particularly evident if two pairs were feeding together; they often moved in a line with the two males on the inside and the two females on the ends, each male preventing the other from approaching his mate. The mated male gave many song spreads to the female
TABLE 1. Location of male-male aggressive encounters of 1966 mated males in relation to their non-feeding range in the study area.

\begin{tabular}{lcccc}
\hline \hline & \multicolumn{2}{c}{ Location of encounters relative to non-feeding range } \\
\cline { 2 - 5 } & $\begin{array}{c}\text { Boundary } \\
\%\end{array}$ & $\begin{array}{c}\text { Outside } \\
\text { boundary } \\
\%\end{array}$ & $\begin{array}{c}\text { Inside } \\
\text { boundary } \\
\%\end{array}$ & $\begin{array}{c}\text { Total number } \\
\text { of encounters }\end{array}$ \\
\hline Aggressor & 26 & 18 & 56 & 106 \\
Recipient & 35 & 21 & 44 & 43 \\
\hline
\end{tabular}

while accompanying her. This defense of the resident female whenever she happened to wander by another male was clear for those pairs that I saw most frequently. The male by his behavior established a monogamous relationship through continued defense of the resident female.

Birds held some degree of attachment to their ranges, since outside males did not invade the study area when I removed 15 mated males in 1967. However minor changes in range did occur-four of nine males that became the mates of the widowed females and three bigamists shifted their ranges when the males were removed. The new ranges of these males incorporated the territories of their new mates, so the amount of shift in range depended on the distance from the male's former range to the female's territory. The territory borders of the females of the three bigamists were adjoining. The males continued to occupy their former ranges as well as their new one. Thus, the extent of a male's range partially depended on the location of his mate's territory.

The return in 1967 of males observed in the 1966 study area (Table 2) also indicated the attachment of different males to the study area. Ten of 12 males mated in 1966 returned, indicating strong attachments. Despite returning to familiar areas only five mated sucessfully in 1967, suggesting that successful competition for the few females was not guaranteed by prior success or familiarity with an area. The 1967 ranges of eight of the mated males that returned overlapped varying proportions of their 1966 ranges. The ninth male was seen once, 4 April 1967, on his 1966 range and the tenth male was seen twice in the study area $200 \mathrm{~m}$ and $700 \mathrm{~m}$ from his 1966 range on 7 and 16 June 1967.

Since 154 males were observed in the study area and 41 were mated males, the status of the remaining 113 requires clarification. In addition to unmated resident males, they probably included non-resident males from nearby areas who were attracted by baiting stations. I examined the behavior of these 113 
TABLE 2. Status of males in 1966 and of those that returned to the study area in 1967.

\begin{tabular}{lcccc}
\hline \hline & \multirow{2}{*}{$\begin{array}{c}\text { Number } \\
\text { of males } \\
\text { seen }\end{array}$} & $\begin{array}{c}1967 \text { status of males that returned } \\
\text { to study area }\end{array}$ \\
\cline { 3 - 5 } & in 1966 & Mated & $\begin{array}{c}\text { Unmated } \\
\text { residents }\end{array}$ & $\begin{array}{c}\text { Non- } \\
\text { residents }\end{array}$ \\
\hline Mated & 12 & 5 & 3 & 2 \\
Unmated residents & 9 & 0 & 2 & 0 \\
Non-residents & 29 & 4 & 2 & 7 \\
\hline
\end{tabular}

males to assess the reasons for their presence and classify the birds.

Since all of the 41 mated males were observed more than five times I assumed that males seen less frequently were more likely to be non-residents. These were examined as a group; 76 of the 113 males were seen five times or less. The activities attributed to 167 observations of their behavior were feeding $(51 \%)$, agonistic encounters (13\%), courtship (17\%) and other (19\%) e.g., flying, sitting, preening and alarm call and accent song.

I examined the courtship and agonistic behavior to determine if some of these males might be residents who were sighted infrequently. Their courtship behavior included song spread, guarding, copulation and following (Table 3). Three of the eight observations of song spread towards resident females involved the same pair of birds suggesting a possibly mated pair. In the other five song-spread displays to resident females, the mates of these females were not present although in one case the female's mate arrived immediately after the display and chased the other male away. Both observations of guarding a resident female (Table 3) involved the same possible mated pair mentioned above. I observed copulation only once, 5 May 1966, in the female's territory one week after she first appeared there. This female became mated to another male. In three cases in which males followed resident females (Table 3), the mates of these females also accompanied them. Based on courtship behavior only, one male who was seen five times or less may have been a mated male.

All but one of the agonistic encounters occurred between males. In the male-female agonistic pattern a male chased a non-resident female away from a resident female, who had just given a number of threat displays to the non-resident female. In 36 agonistic patterns, including song spread, group song spread, billup, flight bill-up and chasing, only $33 \%$ of the recipients were mated males, suggesting that most of these encounters involved strangers to the study area.

All but one of the 76 males observed five times or less were considered to be non-residents. The status of this single male was not certain; he exhibited guarding and song-spread behavior with a resident female and appeared to be mated to her. The other 75 males showed little agonistic behavior towards mated males or courtship behavior towards breeding resident females. The courtship with resident females that did occur was observed when their mates were absent. Since much of the courtship and aronistic behavior by these birds was seen with non-resident recipients, these males probably resided outside the study area. They came to the study area accompanied by others primarily to feed and continued courtship and agonistic behavior while there.

The behavior of the 37 unmated males seen more than five times was also examined to determine why they were in the study area. The activities (624 actions in 543 observed instances) in the area were feeding $(41 \%)$, agonistic encounters (17\%), courtship (20\%), and other functions (22\%) including: sitting, flying, stretching, preening, alarm call and accent call. The recipients of the courtship and agonistic behavior were examined to determine the associates of the 37 males. The courtship behavior included song spread and guarding and following (Table 3 ). In 24 of 25 observations of song spread to resident females (Table 3),

TABLE 3. Female recipients of courtship patterns performed by 1) males observed five times or less in the study area and 2) males observed more than five times in the area.

\begin{tabular}{|c|c|c|c|c|c|c|}
\hline \multirow{2}{*}{$\begin{array}{l}\text { Number of } \\
\text { observations } \\
\text { of males in } \\
\text { study area }\end{array}$} & \multirow[b]{2}{*}{ Courtship behavior patterns } & \multirow{2}{*}{$\begin{array}{l}\text { Number of } \\
\text { behavior } \\
\text { patterns }\end{array}$} & \multicolumn{4}{|c|}{ Female reactors } \\
\hline & & & $\begin{array}{l}\text { Breeding } \\
\text { residents }\end{array}$ & $\begin{array}{l}\text { Non- } \\
\text { residents }\end{array}$ & $\begin{array}{l}\text { Unbanded } \\
\text { birds }\end{array}$ & $\begin{array}{c}\text { Unknown } \\
\text { birds }\end{array}$ \\
\hline \multirow[t]{4}{*}{$\leq 5$} & a) Song spread & 13 & 8 & 5 & & \\
\hline & b) Guarding & 8 & 2 & 5 & 1 & \\
\hline & c) Copulation & 1 & 1 & & & \\
\hline & d) Following & 14 & 3 & 1 & 5 & 5 \\
\hline \multirow[t]{3}{*}{$>5$} & a) Song spread & 52 & 25 & 4 & 19 & 4 \\
\hline & b) Guarding & 26 & 14 & 4 & 8 & \\
\hline & c) Following & 65 & 29 & 12 & 12 & 12 \\
\hline
\end{tabular}


the mate of the female recipient was not present. Similarly, in 13 of 14 observations of guarding behavior with resident females (Table 3) the mates of the females were not present, but one female's mate arrived just after the display and displaced the male that exhibited the guarding. Forty-nine percent of the song spreads and guardings were performed by 3 of the 37 males. One gave 9 of 10 observed displays to unbanded female(s) (probably a single unbanded female) and a second male displayed seven times to unbanded female(s) (probably a single female). These unbanded females may have been residents and the two males their mates. The third male displayed 21 times: 7 to unbanded females, 2 to a nonresident and 12 to two resident females. This male appeared to be an unmated resident of the study area. In $45 \%$ of the instances in which females were followed, the bird who was followed was a resident. In $55 \%$ of these cases the mate of the resident female also followed the female. None of the 37 males consistently followed any particular resident female, indicating that the males were probably not mated to any of these females. Their courtship behavior, in cases where the participants were known, appeared opportunistic. When the mate was absent they courted the female.

In 136 male-male agonistic encounters by the unmated males, including song spread, group song spread, bill-up, flight bill-up, supplanting and retreating, 55\% of the 179 recipients were mated resident males. Twenty-two percent more agonistic encounters with mated residents occurred in this group than those seen in the group observed five times or less. This supports the view that they were unmated residents interacting more frequently with the residents. Some males were often seen feeding in the study area. Eight of the 37 males accounted for $50 \%$ of the 258 feeding observations; these males were probably unmated residents.

Two of the 37 males who were seen more than five times appeared to be mated to unbanded females. A third male courted a number of females. The remaining 34 males did not court any particular females. The few courtship displays directed to resident females usually occurred when their mates were absent. Only two of nine males observed more than five times in 1966 returned to the study area; one of them was found once in 1967300 $\mathrm{m}$ from his former range. The other was seen four times in 1967, $600 \mathrm{~m}$ from his 1966 range. Most of these males appeared to be unmated, although some may have had mates outside the study area. The proportion of agonistic encounters of these males with mated males was significantly higher (chi-square, $0.015>P>0.01$ ) than the proportion of agonistic encounters of males observed five times or less with mated males. This suggested that many of the frequently sighted males were unmated residents and were considered rivals by mated resident males.

The ranges of unmated males $(8.7 \pm 2.2 \mathrm{ha})$ were larger than those of mated males $(6.6 \pm$ $1.4 \mathrm{ha}$ ) found in the study area in 1967. For this comparison the ranges of 17 unmated males seen 10 or more times in the study area were compared to the ranges of 17 mated males (the nine replacement males and three bigamous males were excluded from this analysis). The values, although not significant at the 0.05 level, suggested a difference in the ranges of these two groups of males (student's $t$-test, $0.1>P>0.05$ ). The movements of mated males may have been restricted by their attendance to the females, who have smaller territories (Darley 1968). Unmated males, not limited by the movements of particular females, were free to range more widely.

On five occasions between 27 June and 6 July 1967 I spent a total of $8 \mathrm{~h}$ outside the study area searching for birds that I had seen in the area. Eight of 83 unmated males were found; two were $300 \mathrm{~m}$, three $400 \mathrm{~m}$, two 450 $\mathrm{m}$, and one $900 \mathrm{~m}$ from the nearest edge of the study area. Five of these males were seen more than five times in the study area and three were seen five times or less. In addition to these unmated males, I saw one mated male $300 \mathrm{~m}$ from the study area. The higher frequency of apparent unmated males found outside the area may have been due to their weak attachments to specific areas or they may have been mated to females outside the study area.

Male cowbirds appeared to establish a hierarchy among themselves, dominant males being mated to the resident breeding females. Dominance was determined in 18 witnessed male-male encounters between mated and unmated males (retreat, supplant and chase behavior). Mated males were dominant in 16 cases and unmated males were dominant in 2 . Dominance was found in significantly more mated than unmated males and subordination was found in significantly more unmated males than mated males $(P>0.005$, chisquare test).

On one occasion a mated male dominated another mated male. The dominant bird returned to his mate's territory to find an interloper (mated to another female) with his female; he immediately established dominance over the interloper. In this conflict the winner was with his mate in her territory, the loser was alone outside his female's territory. This 
observation suggested two possible factors that may affect success in an aggressive encounter: the presence of a mate or proximity to mate's territory. These factors were examined for all mated males. The presence of the mated female did not seem to influence dominance in the encounters. In the 17 cases when the mated male dominated, the females were present in 8 and absent in 9. The location of the encounters relative to the female's territory did not seem related to dominance either, as 10 were within the territory and 7 outside. Thus, these two factors did not seem directly related to dominance.

I did not have enough data to determine if hierarchies were present within groups of mated males or unmated males, but limited information suggested this to be the case. Males usually remained mated to the same female for the whole breeding season. One male was last seen with his mate 16 May 1967 ; another male apparently took over this female 19 May. The first male mated with another male's female, and the third male did not get another female. These few observations suggested the existence of hierarchy within mated males, i.e., when the first male lost its mate to a dominant male it took over the mate of a subordinate male.

In addition to the mated and unmated males, I captured unbanded males at the banding station throughout the breeding season in 1967. In order to determine if there were any differences in the breeding condition of mated and unmated males and of unbanded males, 53 males were killed and their testes were examined. In 31 of 35 banded males the testes contained mature sperm (stages 5, 6, 7; Scott and Middleton 1968) and the testes of the other four males were in the regressed condition (stage 9). The testes of 11 mated males were indistinguishable from those of the 24 unmated males. In the 18 unbanded males all had mature sperm present in their testes except for one with regressed testes. Thus, all the males were in breeding condition or recently had been, so the difference between mated and unmated males was not reflected by a difference in testis development.

\section{DISCUSSION}

Observations of male cowbird territorialism by other workers have been varied. Friedmann (1929) stated "the male has a definite post, entirely comparable to the 'singing tree' that Mousley described." He could not be certain of the identity of males in these trees because his birds were not banded. He concluded that the male was territorial because it could be found almost constantly on the same perch in the same tree. Friedmann also stated that "the cowbirds do not make any very spirited attempts to defend their territories and consequently in regions of unusual abundance the territorial factor is much less noticeable." Nice (1937) likewise noted that her banded cowbirds had definite ranges but showed no territory defense. In a study of banded cowbirds attracted to a baited area, Laskey (1950) observed many threats and fights but they did not appear to be in defense of territory. She stated "I witnessed no sustained effort to keep males or females out of a preempted area." One pair seemed to be dominant over other cowbirds which fed in the area. She stated "I believe the dominant pair showed vestigial territory behavior in intimidating others and keeping the domain for their own in pair formation and mating." Rothstein (1972) stated that male cowbirds were territorial in the morning but not in the afternoon, basing this on observations that dominant males sang in the morning but allowed subordinate males to sing in the afternoon.

The males in my study area restricted their movements to specific ranges and often occurred in particular trees. However, they did not defend these ranges or trees, and different males were often seen in the same "singing trees." Since defense is an integral part of the concept of territory, these areas should not be called territories but ranges.

Although males did not defend territories they clearly defended specific females. Mated males prevented other males from approaching their mates and accompanied their females most of the time.

When watching potential hosts nesting, a female commonly chased away all cowbirds accompanying her including her mate. On completing these solitary activities she frequently flew near her male's "singing tree" and gave the chatter call. Her male or any other birds joined her and the social behavior resumed. Occasionally her male was absent and it was at these times that interlopers engaged in courtship. They were chased by her mate when he returned and her mate resumed guarding.

Guarding the female has been observed in other birds. Williams (1952) reported this for Brewer's Blackbird (Euphagus cyanocephalus) and Ficken (1963) reported that the male Common Grackle (Quiscalus quiscula) guarded his mate and a small area around the nest site.

Mated males dominated over other males even when their female was absent. The effect of dominance on pairing was seen when 15 mated males were removed in 1967. Three of the replacement males were already paired, 
i.e., they became bigamists. This bigamy occurred in spite of the presence of unmated males. The dominant male got two mates and the subordinate male none. Laskey (1950) also reported "females in an area of her own choosing accepted the dominant male of the same area as her mate."

Is there a complex social hierarchy within the male society or is it simply that the dominant male in the area gets the female? Laskey (1950) stated "There was no indication of a peck-order similar to that described by Allee for domestic chickens (Nice 1943: 92) nor of a society comparable to that of Jackdaw (Corvus monedula)." However, in an experiment with captive birds including four males and two females, I found a straight-line hierarchy (Darley 1978). Also King and West (1977) stated "Data from our laboratory indicated that cowbirds have highly structured dominance hierarchies and complex intraspecific behaviors that may also facilitate identification or maintain social integration among acquainted cowbirds." Some field data supported this view. One male usurped the female of a second male who in turn took the female of a third. The third male did not get another female. In addition, dominance was not dependent on the presence of a female or proximity to the female's territory. Dominance was established in some other way.

The presence of a dominance hierarchy in males would account for some cowbird behavior. Males regularly engage in what Laskey (1950) called "triangle and quadrangle ceremonies." I observed a number of males (three-six) form circles on the ground or in the trees and proceed to give elaborate song spreads, usually one after the other, to the other males. The individual song spread sometimes was directed to an adjacent male and at other times apparently to the group. These group song spreads continued throughout the season and may have been the ritual by which the dominance hierarchy was established and maintained. Laskey (1950) also noted indications of this dominance.

A hierarchy could also account for the lack of territorial defense by the males and the widely overlapping ranges that they did occupy. There was no reason to restrict other males since the dominant male mated with the resident female. The existence of a hierarchy would also explain why, when dominant males were absent from their females, individual subordinate males defended the female. Thest were chased when the dominant male returned, i.e., they were not mated but were simply acting as opportunists.

The differing conclusions about territorial- ism reached by other workers could be attributable to several behavioral factors. Males behaved agonistically in defending females and establishing a dominance hierarchy with other males. The many agonistic encounters noted by other observers, in addition to restriction in movements by the males, may have been interpreted as territorial behavior.

The discrepancies in published descriptions of monogamy versus promiscuity for cowbirds can be attributed to many factors, several of which have already been discussed in detail. Absolute monogamy requires not only a bond by a male with a specific female but also a corresponding bond by the female with the same male. This did not always occur in this population of cowbirds. Males did establish bonds with resident females. Some females in turn appeared bonded to the males, guarding them and chasing off intruding females (Darley 1968). Other females did not show such behavior and consorted with any male available. Indeed, three of seven copulations involved males other than their mates. However, if dominant males constantly attend the resident females this maximizes their chances for reproductive behavior and, being dominant, they are more likely to copulate than their subordinate counterparts. Thus, monogamy appears the rule from the male point of view. Females, faced with an excess of potential mates, do not show the monogamous tendency of males. Thus absolute monogamy did not exist for all pairs because of the female behavior. However, the constant attendance of the different dominant males to all the resident females ensured a monogamous community for the most part. Factors such as these could account for the discrepancies observed in the literature regarding cowbird relationships.

\section{ACKNOWLEDGMENTS}

This work is a portion of a doctoral dissertation presented at the University of Western Ontario. I thank my supervisor, D. M. Scott, for his interest and guidance. This work was supported through grants from the National Research Council to D. M. Scott.

\section{LITERATURE CITED}

DARLEY, J. A. 1968. The social organization of breeding Brown-headed Cowbirds. Unpubl. Ph.D. diss., Univ. of Western Ontario, London.

DARLeY, J. A. 1971. Sex ratio and mortality in the Brown-headed Cowbird. Auk 88:560-566.

Darley, J. A. 1978. Pairing in captive Brown-headed Cowbirds (Molothrus ater). Can. J. Zool. 56:2249-2252.

FICKEN, R. W. 1963. Courtship and agonistic behavior of the Common Grackle (Quiscalus quiscula). Auk 80:52-72.

FriedmanN, H. 1929. The cowbirds, a study in the biology of social parasitism. Charles C Thomas, Springfield, IL. 
KING, A. P., AND M. J. West. 1977. Species identification in the North American cowbird: appropriate responses to abnormal song. Science 195:1002-1004.

LASKeY, A. R. 1950. Cowbird behavior. Wilson Bull. 62:157-174.

$\rightarrow$ MCIlhenny, E. A. 1940. Sex ratio in wild birds. Auk 57:85-93.

NICE, M. M. 1937. Studies in the life history of the Song Sparrow, I. Trans. Linn. Soc. N.Y., 4.

NICE, M. M. 1943. Studies in the life history of the Song Sparrow, II. Trans. Linn. Soc. N.Y., 6.

Orians, G. H., and G. M. Christman. 1968. A comparative study of the behavior of Red-winged, Tricolored, and Yellow-headed blackbirds. Univ. Calif. Publ. Zool. 84:1-85.

RothSTEIN, S. I. 1972. Territoriality and mating system in the parasitic Brown-headed Cowbird (Molothrus ater) as determined from captive birds. Am. Zool. 12:659.

Condor 84:21

(c) The Cooper Ornithological Society 1982

\section{RECENT PUBLICATIONS}

Form and Function in Birds, Volume 2.-Edited by A. S. King and J. McLelland. 1981. Academic Press Inc., London. 496 p. \$97.00. This volume matches the first (noted in Condor 82:327) in treatment, authority, and format. It contains long, detailed chapters on the male genital organs (by P. E. Lake), cloaca and phallus (A. S. King), endocrine glands (R. D. Hodges), cardiovascular system (N. H. West, B. Lowell Langille, and D. R. Jones), lymphatic system (M. E. Rose), cranial nerves (A. Bubién-Waluszewska), and the functional anatomy of the avian jaw apparatus (P. Buhler). The text is generously illustrated with drawings, diagrams, photographs, and photomicrographs but the reproduction of the halftones is only mediocre. One cannot but regret that the book is so costly because it is certainly the best reference for its subjects, an important work for avian anatomists, physiologists, and pathologists. Lists of references, index.
Scott, D. M., AND A. L. A. Middleton. 1968. The annual testicular cycle of the Brown-headed Cowbird (Molothrus ater). Can. J. Zool. 46:77-87.

SCOTT, D. M., AND C. D. ANKNEy. 1980. Fecundity of the Brown-headed Cowbird in southern Ontario. Auk 97:677-683.

SNedeCor, G. W. 1956. Statistical methods. Iowa State Univ. Press, Ames.

Steel, R. G. D., AND J. H. Torrie. 1960. Principles and procedures of statistics. McGraw-Hill Book Co., New York.

Williams, L. 1952. Breeding of the Brewer's Blackbird (Icteridae). Condor 54:3-47.

Department of Psychology, Saint Mary's University, Halifax, Nova Scotia B3H 3C3, Canada. Accepted for publication 23 January 1979.
Wildfowl 32.-Edited by G. V. T. Matthews and M. A. Ogilvie. 1981. Wildfowl Trust, Slimbridge. 176 p. Paper cover. \$13.00. Source: Administrative Officer, Wildfowl Trust, Slimbridge, Gloucestershire GL2 7BT, England. The 21 articles in this volume variously concern the behavior, ecology, populations, feeding, activity budgets, and other aspects of anseriforms and other waterbirds around the world. Following these are seven reports from the International Waterfowl Research Bureau and The Wildfowl Trust. The biological emphasis and cosmopolitan scope of the preceding volume (noted in Condor 83:255) are admirably continued here. This series has become an important publication for waterfowl biologists far beyond Slimbridge. As before, this volume carries a color painting on the cover and several drawings by Peter Scott, in addition to the scientific illustrations. 